\title{
AN INVESTIGATION ON PATHOGENIC MICRO - ORGANISMS OF PARACENTROTUS LIVIDUS AND HOLOTHURIA POLII (ECHINODERMATA) MEDITERRANEAN SEA EGYPT.
}

\author{
Nahla E. Omran and Samia H. Eissa \\ Zoology Department, Faculty of Science, Tanta University,Egypt.
}

Key words: Sea urchin, Sea cucumber, Echinodermata, microoganisms,

Bacteria, Fungi, Abu-Qir coast, Alexandria

\begin{abstract}
Microbiological studies of two echinoderms, the Sea Urchin, 1 Paracentrotus lividus and the Sea cucumber, Holothuria polii from Abu-Qir region of Alexandria Mediterranean coast, were conducted during July 2005. The isolates revealed Gram-positive bacteria from the gonads of the sea urchin and two types of pathogenic fungi from its digestive tract. On the other hand, no isolates were detected from the sea cucumber. The effect of the isolated microorganisms was discussed.
\end{abstract}

\section{INTRODUCTION}

Potential pathogens are present in the marine environment (Bonde, 1977) and may occur naturally on the surface of marine animals (Unkles, 1977; Roberts-Regan et al., 1988) and as gut associated bacteria in Echinus esculentus (Unkles, 1977).

There is yet little information on the causative organisms of the diseases of echinoderms. Interest in the marine microbial flora of both temperate and tropical sea urchins has dramatically increased since the catastrophic 1983/1984 mass mortality of Diadema antillarum, throughout the Caribbean and Tropical West Atlantic Oceans (Lessios et al., 1984). Besides, there are many reports (Miller \& Colodey, 1983; Scheibling \& Stephenson, 1984; Jones \& Scheibling, 1985) related to naturally occurring mass mortality of sea urchin. Gilles Pearse (1986) reported that the pathogenic agent of the sea urchin disease could be a bacterium. Also, Hamaguchi et al. (1993) reported that the disease of the sea urchin Paracentrotus depressus in summer season was due to a kind of gliding bacterium, which was isolated from the diseased sea urchin. 
Almost nothing is so far known about bacterial diseases in holothuroids. However, there is a single note reporting that a brood stock of Holothuria scarba from Bribie Island (Australia) suffered from a bacterial disease (Morgan, 2000).

In Egypt, few studies were carried out on pathogenic bacterial diseases of freshwater invertebrates. Sharshar (2002) discussed the effect of some bacterial infection (not identified) associated with spontaneous mortality among cultured freshwater prawn Macrobracium rosenbergii. Another study was done by Geasa (2003), who isolated three types of bacteria from the haemolymph of Procambarus clarkia, namely: Pseudomonas aeruginosa, Salmonella sp and Shigella sp . Meanwhile, no pathogens had been isolated from any sea invertebrate. This preliminary work might provide a basic knowledge of the internal microbial flora, which may invade the echinoderm tissue.

\section{MATERIAL AND METHODS}

Two common echinoderms namely Paracentrotus lividus ( Echinoidea ) and Holothuria polii ( Halothuroidea ) were collected from an intertidal region at Abu-Qir coast Eastern Alexandria (Mediterranean Sea) during July, 2005. The samples were transferred alive to the laboratory, where they were put in precleaned sterile aquaria filled with seawater obtained from the same area of collection. Samples of gonads and intestine of fifty sea urchins and intestine of twenty-five sea cucumbers were dissected out of the animals and sent to Microbiology $\mathrm{Lab}$ at the same day of collection for bacterial and fungal analysis.

Samples were inoculated on different specific media and incubated aerobically and anaerobically at $37^{\circ} \mathrm{C}$ for $24-48 \mathrm{hrs}$ for bacterial growth. Suspected colonies were picked up and purified by subculturing on blood agar plates (Difco Manual, 1974). Pure bacterial isolates were identified according to the morphological cultural and biochemical characteristics (Cruickshank et al., 1980). The media used were nutrient agar (Difco Manual, 1974), Sabouraud agar (Booth, 1971) and Macconky agar (Oxoid Manual, 1981). The confirmatory test for bacteria was catalase test (Oxoid Manual, 1981).

Pathogenic fungi were isolated on Sabouraud agar and characterized by light microscope. Sabouraud agar was supplemented with $0.1 \%$ cyclohexamide to select the pathogenic fungi from saprophytic fungi. 


\section{RESULTS}

Gonads of Paracentrotus lividus:

Cultures of different parts of gonads yielded one bacterial morphotype. All the bacterial populations in the culture were Gram-Positive Staphylococcus aureus. Percentage of infection was 100\%. Growing of bacteria was aerobically at $37^{\circ} \mathrm{C}$ on nutrient agar produced indopigment, which is golden yellow, while in blood agar produced hemolysis. Morphological observations revealed that they are simple, rounded with membrane-bound vesicles and with little organization to their cell structure. They were arranged in random aggregations. None of them exhibited evidence for flagella or pili nor showed any type of motility (Fig. 1).

\section{Gut of P. lividus:}

No bacterial isolates were produced from the gut. On the other hand, two types of pathogenic fungi were isolated from the extracts of the digestive tract tissues. They were Aspergillus niger and Aspergillus flavus. They were differentiated from each other by the colour of their colonies, that was black in A. niger and green in A. flavus. Both were cultured on Sabouraud agar at $25-37{ }^{\circ} \mathrm{C}$ and the colony had a powdery surface. The two fungi were formed, each of an aerial hypha (mycelia) and swollen rounded end, while the conidiophores that carry conidia or spores were arranged in chains (Figs. 2 and 3). None of the infection present induced any detected external disorder sign.

\section{Holothuria polii}

Concerning the Sea cucumber Holothuria polii, microbiological studies revealed no bacterial or fungal infection in its intestine or tegument.

\section{DISCUSSION}

The results obtained showed the presence of three microorganisms in the intestinal and gonadal tissues of the sea urchin, Paracentrotus lividus. They included the round-shaped bacteria, Staphylococcus aureus and two species of fungi, namely Aspergillus flavus and A. niger.

Previous investigators also have found Gram-positive bacteria in temperate echinoids (Bauer \& Agerter, 1994). Unkles (1977) recovered a high incidence of Gram-positive organisms (not identified) from the peristomial membrane; however none was isolated from the gut. Mareouer, Roberts-Regan et al. (1988) cultured Gram-positive rods and 
cocci from surface lesions on Strogylocentrotus droebachiensis but did not identify the isolates.

Also, Previously, Staphylococcus aureus has been isolated at levels of $2-10 \%$ from fish and bivalves, but much more commonly in cooked, handled crustaceans where as much as $42-52 \%$ of samples may be positive (Jablonski \& Bohach, 1997). The present findings differ from all the previous studies in that, in addition to bacteria, there were also two species of fungi that were recovered from the gut of most of the examined specimens. To our knowledge, this is yet the first time that fungi were reported from sea urchin.

The pathogenicity of these microorganisms for the present sea urchin was unclear, since histopathological studies of gonads and intestine revealed no changes in their structures and no detected external signs. The absence of pathological signs may be due to that collection of samples occurred at the beginning of infection, consequently these types of pathogens had no chance to induce the disease, or that the immunological defense of the animal can overcome the infection. The present data open the possibility that organisms loosely coexisting with sea urchins could provide protection for such animals against the harmful growth of pathogens. It can also be attributed to the presence of antibacterial factors as described by Stabili et al. (1996) who stated that the eggs of Paracentrotus lividus contain antibacterial agent called lysozyme-like antibacterial factor which is widespread in the reproductive tissue of echinoderms. This antimicrobial activity has been found in the eggs of other marine invertebrates. (Benkendorff et al., 2001 ; Haug et al., 2002). However, it is possible for the sea urchins to act as carriers for pathogenic bacteria and fungi which may cause serious diseases for humans, where ingestion of Staphylococcus aureus cause nausea, vomiting, stomach cramps and some times diarrhea and toxic shock syndrome (Gram \& Huss, 2000). Moreover, both Aspegillus niger and A. flavus can cause pulmonary diseases producing tumors in lungs and bronchi, asthma attacks and external ear infection (Arthur et al.,1992; Abla, 2005).

It has been reported that the tegument of some species of sea cucumber contains a substance called holothurin which has anti-tumor and antifungal activities (Anisimov et al., 1980 ; Kuznetsova et al., 1982), as well as an anti-bacterial effect (Ridzwan et al.,1995 ; Noah et al., 2001). Therefore, the absence of such pathogens from the present sea 
cucumber may be attributed to the presence of this substance (holothurin), which acts as a barrier against the infection.

\section{Conclusion and recommendations:}

1- It is recommended to avoid eating row gonads of sea urchins or handling there viscera to avoid possible pathogenic diseases.

2- Sea urchins are considered as good indicator to express pollution by sewage discharged into the area of collection (Abu-Qir, Alexandria).

3- Further investigations are needed to reveal the ability of sea cucumber to face the pollution.

\section{REFERENCES}

Abla, M. El-Mishad (2005). Manual of medical and Microbiology and Immunol. II. Fourth edition.

Anisimov, M.M.; Prokofieva, G.N.; Korotkikh, L.I.; Kapustina, I.I. and Stonik V.A. (1980). Comparative study of cytotoxic activity of triterpene glycosides from marine organisms. Toxicon. 18: 221-223.

Arthur, G.J.; Richard, Z.; Thomas, J.F.; Omelan, L.; Louise, H. (1992). Microbiol \& Immunol. Mass publishing.

Bauer, J.C. and Agerter, C. J. (1994). Isolation of potentially pathogenic bacterial flora from tropical sea urchins in selected West Atlantic and east Pacific sites. Bull. Mar. Sci., 55 (1): 142-150.

Benkendorff, K.; Davis, A. R.; Bremner, J. (2001). Chemical defense in the egg masses of benthic invertebrates: an assement of antibacterial activity in 39 mollusks and 4 polychaetess. J. Invertbr. Pathol., 78: 109-118

Bonde, G.J. (1977). Bacterial indication of water pollution. In: Droop, M.R., Jannasch, H.W. (ed.) Advances in aquatic microbiology, 1. Academic Press, New York, p.273-364.

Booth, C. (1971). Fungal culture media method in microbiology (Booth C., Edn) 4. Academic pres. London. 
Cruickshank, R.; Duguid, J.P.; Marian, B.P.and Swain, R.H.A. (1980). Medical Microbiology, 12 th Edition vol. II Churchill, Livingstone, Edinburgh and London.

DEFCO Manual (1974). Difco Manual of dehydrated culture media and reagent for microbial and laboratory producers 9 th edn.U.K.

Gablonski, L.M. and Bohach G.A. (1997). Staphylococcus aureus. In: Doyle, M.P.; L.R.Beuchat and T.J. Montville (eds). Food microbiology. Fundamentals and frontiers. Asm press. Washington DC, U.S.A. pp.353-375

Geasa, N.M.Sh. (2003). Pathological changes in the exotic crayfish Procambarus clarkii (Crustacea, Decapoda) J.Egypt. Ger.Soc.Zool. 40D: 15-27.

Gilles, K.W. and Pearse, J.S. (1986). Disease in sea urchins Strongylocentrotus purpuratus: experimental infection and bacterial virulence. Dis. Aquat. Org. 1: 105-114.

Gram, L. \& Huss H.H. (2000). Fish and shellfish products. The icrobiology safety and quality of foods. Aspen publishers Inc., Gaithersberg, Mariland, U.S.A.pp.472-506

Hamaguchi, M.; Kawahara, I. And Usuki, H. (1993): Mass mortality of Pseudocentrotus depressus caused by a bacterial infection in summer. Suisanzoshoku, 41: 189-193.

Haug, T.; Kjuul, A. K.; Stensvag, K.; Sandsdalen, E.; Styrvold,O. B. (2002).Antibacterial activity in four marine crustacean decapods. Fish shellfish Immunol. 12 : 371-385.

Jablonski, L. M. and Bohach, G. A. (1997). Staphylococcus aureus.In: Doyle, M.P.L.R. Beuchat and T.J.Monteille (eds). Food Microbiology. Fundamentals and Frontiers.Asm press, Washington.U.S.A.pp.353-375.

Jones, G.M. and Scheibling R.E. (1985). Paramoeba sp. (Amoebida, Paramoebidae) as the possible causative agent of sea urchin mass mortality in Nova Scotia. J. Parasit., 71: 559-565. 
Kuznetsova, T. A.; Anisimov, M.M.; Popov, A.M.; Baranova, S.I.; Afiyatullov,Sh.;Kapustina,I. I.;Antonov, A.S. and Elyakov,G.B. (1982). A comparative studying vitro of physiological activity of triterpene glycosides from marine invertebrates of echinoderm type. Comp. Physiol., 73: 41-43.

Lessios, H.A.; Robertson, D. R. and Cubit, J.D. (1984). Spread of Diadema mass mortality through the Caribbean. Science. 226: 335-337.

Miller, R.J. and Colodey, A.G. (1983). Widespread mass mortalities of the green sea urchin in Nova Scotia, Canada. Mar. Biol., 73: 263-267.

Morgan, A.D. (2000). Aspects de la gestion des stocks geniteurs d'holothuries de sable (Echinoderme: Holothuroides ), La Beche-de-mer Bulletin d'information vol.13. Secretariat general de la communaute du Pacifique, pp.2-8

Noah, R.M.; Sahlan, A.Z.; Yusuf, Z.; Jais, M.R.; Warif, N.A. and Hashim, R. (2001). Antimicrobial action of Holothuria edulis extract and its effect on the oxidative burst of human neutrophils. Third International Symposium on Antimicrobial Agents and resistance, Seoul, Korea, pp: 414.

OXOID Manual (1981). The Oxoid manual of culture media ingredients and other laboratory services 5 th ed. U.K.

Ridzwan, B.H.; Kaswandi, M.A.; Azman, Y.; and Faud, M. (1995). Screening for antibacterial agents in three species of sea cucumber from coastal areas of Sabah.Gen. Pharmacol. 26:1539-1543.

Roberts-Regan, D.L., Scheibting, R.E. and Jellet, J.F. (1988). Naturally and experimentally induced lesions of the body wall of sea urchin Strongylocentrotus droebachiensis. Dis Aquat. Org. 5: 51-62. 
Scheibling, R.E. and Stephenson, R.L. (1984). Mass mortality of Strogylocentrotus droebachiensis (Echinodermata: Echinoidea) of Nova Scotia, Canada.Mar.Biol.,78: 153-164.

Sharshar, Kh.M. (2002). Histopathological and ultrastructural studies on bacterially infected hepatopancreatic cells of the cultured fresh water prawn Macrobrachium rosenbergii (Crustacea, Decapoda) J.Egypt. Ger. Soc. Zool., 391: 17-28.

Stabili, L.; Lassagues, M. and Pastore, M. (1996). Preliminary study on the antibacterial capabilities of eggs of Paracentrotus lividus (Echinodermata: Echinoidea).

Unkles, S.E. (1977). Bacterial flora of sea urchin, Echinus esculentus.Apple. Environ. Microbial., 34: 347-450. 


\section{LIST OF FIGURES}

Fig. 1: A smear of Staphylococcus aureus. Gram stain.X 1000.

Fig. 2: Aspergillus flavus. X 400

Fig. 3: A. niger. X 250

M Mycelium

C Conidiophores

S Spores 